\title{
Perceived Influence of Business Environment on Small and Medium Scale Enterprises Success in Nigeria
}

\author{
Edward Gbadebo Adewole and Titus Amodu Umoru
}

\section{ABSTRACT}

\begin{abstract}
The study examined the perceived influence of business environment on the success of small and medium-scale enterprises in Osun State, Nigeria. The main purpose of the study is to determine the influence of business environment on the success of small and medium-scale enterprises (SMEs). The study adopted descriptive survey research design. Two research questions and two hypotheses guided the study. The population of the study comprised all registered small and medium scale enterprises in Osun State. Two hundred and fifty-five (255) owners/managers of small and mediumscale enterprises were sampled for the study through, proportionate, stratified and systematic random sampling techniques. The instrument for data collection was "Perceived Influence of Business Environment on the Success of SMEs" Questionnaire (PIBESSMEQ). A reliability co-efficient of 0.70 was obtained using Cronbach Alpha. Mean and standard deviation was used to answer the research questions while hypotheses were tested using analysis of variance (ANOVA) at 0.05 level of significance. Findings of the study revealed that business environment influenced the success of SMES to a high extent. Also, the study revealed that no significant difference existed in the influence of business environment on SMEs success in term of their location. Based on the findings, it was concluded that SMEs' success could be better guaranteed with sufficient knowledge of the business environment. The study among others recommended that owners/managers of SMEs should always endeavor to increase their knowledge and skills to a maximum level in order to surmount challenges relating to business environment.
\end{abstract}

Keywords: Business Environment, Small and Medium Scale Enterprises, Success.

\section{INTRODUCTION}

Countries worldwide have acknowledged that Small and Medium Scale Enterprises are indispensable in the economic growth of any country. In Nigeria, Small and Medium Scale Enterprises (SMEs) have played significant roles in economic development since her independence. Small businesses, according to the Small and Medium Enterprise Development Agency of Nigeria (SMEDAN) (2017), are those businesses with total assets (excluding land and buildings) of more than ten million naira but less than one hundred million naira and a total workforce of more than ten but less than forty-nine employees. Medium Enterprises are businesses with total assets (excluding land and buildings) of more than fifty million naira but less than one billion naira and a workforce from fifty to one hundred and ninety-nine workers.

Important roles played by (SMEs) in economic and social development of many countries have continued to grow in recent decades. Thus, small, and medium-sized businesses (SMEs) are widely considered as the engine of economic growth in both emerging and developed economies (Agwu \& Emeti, 2014; Alese, 2017). In this regard, Alese submitted that almost all countries that focused on SMEs sector have enjoyed significant reductions in poverty and the associated improvements in quality and standard of life, as well as a
Submitted : November 29, 2021

Published : December 23, 2021

ISSN: 2507-1076

DOI: $10.24018 /$ ejbmr.2021.6.6.1182

E. G. Adewole*

Department of Business and Entrepreneurship Education, Kwara State University, Malete. Nigeria.

(e-mail: adewoleeg2016@gmail.com)

Prof. T. A. Umoru

Department of Business and Entrepreneurship Education, Kwara State University, Malete. Nigeria.

*Corresponding Author decrease in crime, increase in per capita income, and quick growth in national output. According to Alaye-Ogan (2012), SMEs are vital to the economic development of any country because they provide an excellent source of employment, aid in the development of local technology, and create opportunities for indigenous entrepreneurs. The SME sector is uniquely positioned to absorb up to 80 per cent of employment vacancies, enhance per capita income, add value to raw materials supply, boost export revenues, and increase capacity utilization in critical industries.

Small-scale enterprises became prominent in Nigeria with the establishment of private enterprises in the early 1970s. According to Dugguh (2013), during the 1960s, the Nigerian economy was driven by the agricultural sector, which was followed by the emergence of the oil industry, resulting in a gross underdevelopment of small enterprises and entrepreneurship. The economy's growth was hampered by an over-reliance on agriculture and oil at the expense of small company and entrepreneurial development. Previous research on small firms in Nigeria has found a clear trend of failure during the first five years of operations (Buowari, 2015). These failures are caused in part by the numerous problems that confront small enterprises, such as a lack of managerial, leadership, and marketing skills that would give them a competitive advantage. Furthermore, Okpara (2011) said that 
small business failure in Nigeria was caused by difficulty in obtaining financing, poor implementation of entrepreneurship policies, and corruption. Small enterprises are an important part of the Nigerian economy, providing a large percentage of jobs and helping to alleviate poverty (Shehu et al.,2013) but eighty percent of small enterprises in Nigeria fail within the first five years (Adebisi \& Gbegi, 2013). This high rate of failure has the potential to affect unemployment rates as well as the local and national economies (Obiwuru, Okwu, Akpa, \& Nwankwere, 2011).

The small size nature of SMEs makes the SMEs dynamic and adapts to changes within the market environment compared to large firms (Mazzarol, Clark, \& Reboud, 2013). In the same vein, Watse (2017) stated that the flexibility of SMEs operations provides business experts confidence in their critical position in underdeveloped countries' future industrial progress. In an increasingly competitive world, SMEs with ready and motivated entrepreneurs are expected to flourish, especially if an enabling environment and supportive government policies exist.

Hans (2018) define environment as everything that surrounds a system. The business environment refers to the physical surroundings (including people) in which a company operates. Every firm and business unit functions in a peculiar environment. Such environment presents opportunities or threat from time to time. The business environment is regarded as critical to global economic activity and growth. Therefore, SMEs do not operate in isolation but within a given environment which might shape their performance, survival, and profitability. Business environment of an enterprise consists of the internal and external environmental factors affecting the performance of business enterprises.

Small businesses that intend to achieve their objectives and vision must understand both their internal and external environment. Given favourable policy, environment and support, SMEs can achieve an efficient business performance that would enable them to compete successfully in the global market (Watse, 2017). The internal business environment refers to variables within the company that influence how it does business and how successful it is. Organizational culture, organizational direction, mission and objectives, management structure and nature, human resources, firm's business intelligence, company's brand image and brand equity among others are all part of internal business environment.

Open systems theorists were the first to recognize an enterprise's external environment. They observed that organizations do not operate in self-contained isolated entities, but rather in constant and inescapable contact with the larger system in which they operate (Pearce \& Robinson, 2011). These theorists stated that external environment, consists of factors that affect a business enterprise from outside such as rivalry, consumer behaviour, supplier behaviour, macroeconomics, government policy and global dynamics (Alkali \& Isa, 2012). The external environment has an impact on how a business organization operates, and the degree of that impact is determined by how that impact is managed.

WebFinance (2019) defined success as the completion of an objective or reaching a goal that can be achieved in the workplace or in one's personal life within a specified period of time or within a specified parameter. Business success can be measured by using both financial indicators and nonfinancial indicators. Financial measures of success are made in term of profitability, sales turnover, sales growth and return on investment. An organisation is considered successful, if it is able to generate income, increase profit, and demonstrate some level of growth, as indicated in their sales and income. Non-financial indicators of success include personal satisfaction, personal growth, skill improvement, flexible lifestyle, business survival, customer satisfaction, customer retention, and career progress (Walker \& Brown, 2004).

The Nigerian situation revealed that SMEs have performed below expectation due to a combination of issues which vary from attitudes and habits of SMEs owners through environmental associated factors, economic instability, instability of governments and policies and policy somersaults (Aderibigbe, 2017). The low performance of SMES could affect overall economic development of the state in particular and the country in general if allowed to continue. In the light of this, there is a compelling need to examine the influence of business environment with a view to devising solutions for successful small and medium scale business operations.

\section{LITERATURE REVIEW}

Business environment refers to those factors that are related to a business which affects enterprise decision and business performance. Cherunilam (2018) emphasized that a business's existence and success is determined by its inherent strength (the resources at its disposal, such as physical resources, financial resources, human resources, skill, and organization) and its ability to adapt to the environment. In industrialized countries, a link has been discovered between the operating environment and corporate growth. According to Okpara (2011), insufficient financial assistance, corruption, poor management, inadequate infrastructure, weak managerial skills, and low demand for products and services are among the factors that cause low performance in the SME sector.

The business world is growing complex, and organisations must be able to cope with problems that these complexities presents. Many businesses have been unable to supplement their internal business environment with the external business environment, resulting in organizational inefficiencies and, as a result, being mostly unproductive over time (Kurtulus, 2012). Despite the fact that the Nigerian economy appears to be improving, the poor state of the country's telecommunications, transportation networks (air, highways, trains, and ports), and energy supply are all obstacles to SMEs' organizational effectiveness. These barriers result in substandard goods and services, higher manufacturing costs and commodity prices, and eventual business collapse. Business environment is widely categorized into internal and external environments (Duncan, 1972). The internal environment of an organization is made up of all relevant physical and social variables within the organization, whereas the external environment is made up of all relevant physical and social variables outside the organization's borders. According to Obiwuru, Oluwalaiye, and Okwu (2011), the 
term "business environment" refers to the totality of external and internal factors that influence a company's ability to survive and flourish. The business environment elements listed by Onwukwe and Ifeanacho (2011) include firm improvements in competitiveness and ownership, market, technology, clients and suppliers, laws and government policy, and socio-economic trends. Economic, infrastructure, political, socio-cultural entities, international institutions, and technology environments are all part of the business environment (Blurtit, 2013; Yusuf, 2014). Customers, industry trends, policies and regulations, competitors, customers, suppliers, distributors, substitutes, government activities, demography, the economy, cultural and social influences, innovations and improved technology are all examples of these environmental variables (Adeoye \& Elegunde, 2012).

\section{A. Internal Business Environment}

The internal business environment refers to the internal elements that influence how operations are conducted and how successful they are. The owners, board of directors, workers, the organization's culture, the physical workspace, and all departments that make up the organization are all part of the business' internal environment (the organizational structure). Hans (2018) categorized the internal environment as: Organisational Culture, Organisational Direction, Mission and Objectives, Management Structure and Nature, Human Resources and other Miscellaneous factors which include: (a) the firm's business intelligence, (b) the company's brand image and brand equity, physical assets and facilities, research and technical skills, and marketing resources among others.

\section{B. External Business Environment}

A company's external business environment can be divided into two categories: micro and macro

\section{1) Microenvironment}

The microenvironment, also known as the task environment, refers to the forces that influence an organization's operation in its immediate surroundings. Micro variables do not impact all businesses in a given industry in the same way. It includes the following elements: customers, competitors, suppliers, marketing middlemen, the general public, financiers, regulators, and strategic partners (Kattookaran, 2016).

\section{2) Macroenvironment}

A business and its microenvironment are part of a larger macro environment. This macro environment offers opportunities while also posing risks to a company. The macro forces are generally more uncontrollable, and a company's success is determined by its ability to adapt to the environment. The following elements make up a firm's macro environment: economic environment, political environment, technical environment, social environment, legal environment, cultural environment, and labor environment (Kattookaran, 2016). Consequently, external assessment looks at opportunities and threats in the environment, whereas internal analysis looks at the company's strengths and shortcomings. Both opportunities and threats exist outside the influence of the firm. Any issue that would persist if a particular firm did not exist must be an external environmental element; conversely, it is an internal environmental factor. The impact of the business environment on enterprises varies depending on the economic situation of the country or region $(\mathrm{Ng} \& \mathrm{Kee}, 2012)$. In particular, when the business environment in industrialized countries is stable, enterprises are plainly better off. The impact of the business environment on enterprises in transition economies like China, Thailand, or Vietnam, on the other hand, may be different (Chittithaworn, Islam, Keawchana, \& Yusuf, 2011). The need for SMEs to mitigate the effects of business environment on their businesses is of great importance. Operators and owners of SMEs should be conversant with both internal and external environments.

\section{Purpose of the Study}

The main purpose of this study is to investigate the Perceived Influence of Business Environment on the Success of Small and Medium Scale Enterprises (SMEs). The study specifically:

i. Investigated the perceived influence of internal business environment on the success of small and medium scale enterprises (SMEs).

ii. Ascertained the influence of external business environment on the success of small and medium scale enterprises (SMEs).

\section{Research Questions}

The following research questions formulated in line with the purposes of the study guided the study:

1. To what extent do internal business environment influence the success of small and medium scale enterprises (SMEs)?

2. To what extent do external business environment influence the success of small and medium scale enterprises (SMEs)?

\section{E. Research Hypotheses}

The following null hypotheses were tested at 0.05 level of significance:

Ho1: There is no significant difference in the mean ratings of entrepreneurs from Osun Central, Osun East and Osun West senatorial districts regarding the influence of internal business environment on the success of small and medium scale enterprises (SMEs).

Ho2: There is no significant difference in the mean ratings of entrepreneurs from Osun Central, Osun East and Osun West senatorial districts regarding the influence of external business environment on the success of small and medium scale enterprises (SMEs). 


\section{CONCEPTUAL FramewORK}

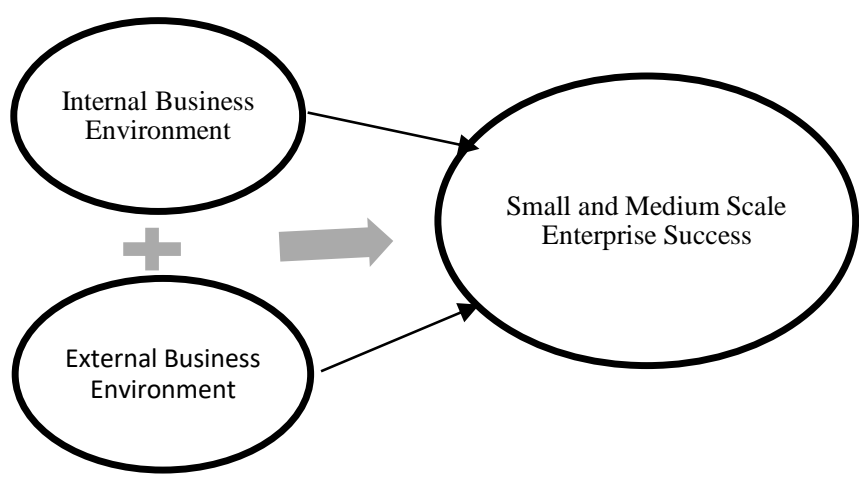

Fig. 1. Conceptual framework of the study.

\section{RESEARCH METHODS}

The study adopted descriptive survey research design. Two research questions and two hypotheses guided the study. The population of the study consisted of all registered small and medium scale enterprises in Osun State. Two hundred and fifty-five (255) owners/managers of small and medium-scale enterprises were sampled for the study using proportionate, stratified, and systematic random sampling techniques. The instrument for data collection was "Perceived Influence of Business Environment on the Success of SMEs" Questionnaire (PIBESSMEQ) A reliability co-efficient of 0.70.was obtained using Cronbach Alpha. The questionnaire was structured on a four-point modified Likert rating scale with response options as follows: Very High Extent (4 points), High Extent (3 points), Low Extent (2 points), and Very Low Extent (1 point). Mean and standard deviation was used to answer the research questions while hypotheses were tested using analysis of variance (ANOVA) at 0.05 level of significance. The hypotheses were tested using independent samples t-test and one-way Analysis of Variance (ANOVA). The decision rule for research question was that any item with a mean of 2.50 and above were scored high extent while those with mean of 2.49 and below were scored low extent. The decision rule for the hypotheses was reject null hypothesis if $F$ is greater than $F_{0.05}$, and accept null hypotheses if $F$ is less than $\mathrm{F}_{0.05}$.

\section{RESULTS}

\section{A. Research Questions}

\section{1) Research Question One}

To what extent do internal business environment influence the success of small and medium scale enterprises (SMEs)?

Analysis of data in Table I shows mean and standard deviation of responses on the extent to which internal business environment influence the success of small and medium scale enterprises. All the 14 constructs have standard deviation ranging from 0.43 to 1.05 . This means that the responses of the respondents are not widespread as they are close to the mean. Table I shows a ground calculated weighted average mean and standard deviation of 2.78 and 0.79 , which indicated that all the constructs influenced the success of small and medium scale enterprises (SMEs) to high extent.

\section{1) Research Question Two}

To what extent do external business environment influence the success of small and medium scale enterprises (SMEs).

Analysis of data in Table II shows mean and standard deviation of responses on the extent to which external business environment influence the success of small and medium scale enterprises. All the 15 constructs have standard deviation ranging from 0.80 to 0.98 . This means that the responses of the respondents are not widespread as they are close to the mean. Table II shows a ground calculated weighted average mean and standard deviation of 2.69 and 0.86 , which indicated that all the constructs influenced the success of small and medium scale enterprises (SMEs) to high extent.

TABLE I: INTERNAL ENVIRONMENT AND BUSINESS SUCCESS

\begin{tabular}{|c|c|c|c|c|}
\hline $\mathrm{S} / \mathrm{N}$ & Item Statements & $\overline{\mathrm{X}}$ & SD & Remark \\
\hline 1. & Non-availability of skilled labour affected my business performance. & 2.41 & 0.43 & Low extent \\
\hline 2. & Lack of dedicated and committed workers delayed my business progress. & 2.39 & 0.93 & Low extent \\
\hline 3. & High labour turnover affected my business' production plan. & 2.43 & 0.99 & Low extent \\
\hline 4. & Staff incompetency reduced my business' output. & 2.17 & 0.96 & Low extent \\
\hline 5 . & Lack of creativity and innovation by employees delayed my business performance. & 2.32 & 0.97 & Low extent \\
\hline 6. & Lack of cooperation among employees reduced business output. & 2.16 & 0.87 & Low extent \\
\hline 7. & $\begin{array}{l}\text { Fraud and pilfering of business' money and properties led to loss of profit in my } \\
\text { business. }\end{array}$ & 2.29 & 1.00 & Low extent \\
\hline 8. & Mismanagement of fund caused loss of business' profit. & 2.31 & 1.05 & Low extent \\
\hline 9. & Job satisfaction among employees helped to increase productivity. & 3.33 & 0.66 & High extent \\
\hline 10. & The adopted leadership style encouraged employees' performance in my business. & 3.45 & 0.66 & High extent \\
\hline 11 & $\begin{array}{l}\text { Prevailing of trust between the subordinate and the superior led to smooth business } \\
\text { operations. }\end{array}$ & 3.35 & 0.69 & High extent \\
\hline 12 & Adoption of the principle of quality management improved my business s' efficiency. & 3.37 & 0.61 & High extent \\
\hline 13 & Good teamwork contributed to my business' success. & 3.50 & 0.62 & High extent \\
\hline \multirow[t]{2}{*}{14} & Firm's business intelligence helped me to maximize business opportunities. & 3.44 & 0.61 & High extent \\
\hline & Weighted average & 2.78 & 0.79 & High extent \\
\hline
\end{tabular}

Source: Field Survey, 2021. 
TABLE II: EXTERNAL ENVIRONMENT AND BUSINESS SUCCESS

\begin{tabular}{|c|c|c|c|c|}
\hline $\mathrm{S} / \mathrm{N}$ & Item Statements & $\overline{\mathrm{X}}$ & SD & Remark \\
\hline 1. & Tax policy and rates reduced my business profit. & 2.70 & 0.90 & High extent \\
\hline 2. & Exchange rate increased my cost of business operation. & 3.18 & 0.85 & High extent \\
\hline 3. & Inflation rate reduced my business profit. & 3.14 & 0.91 & High extent \\
\hline 4. & Reduction in people's purchasing power reduced patronage of my business' products. & 3.25 & 0.82 & High extent \\
\hline 5. & Lack of good roads disturbed my business activities. & 3.16 & 0.90 & High extent \\
\hline 6. & Unstable power supply reduced my business output. & 3.23 & 0.80 & High extent \\
\hline 7. & Bad communication network delayed my business transactions. & 2.71 & 0.89 & High extent \\
\hline 8. & Inadequate government support delayed my business expansion. & 3.39 & 0.80 & High extent \\
\hline 9. & Unfair competition within industry led to loss of profit in my business. & 2.39 & 0.78 & Low extent \\
\hline 10. & Expensive advertising media increased my cost of production & 2.29 & 0.87 & Low extent \\
\hline 11 & Cultural and religious practices reduced patronage of my business products. & 1.74 & 0.89 & Low extent \\
\hline 12 & Environmental insecurity disturbed my business activities. & 2.46 & 0.95 & Low extent \\
\hline 13 & Customer's population limited my business profit. & 2.51 & 0.81 & High extent \\
\hline 14 & Changes in taste and fashion reduced my business patronage. & 2.00 & 0.80 & Low extent \\
\hline \multirow[t]{2}{*}{15} & Population distribution limited my volume of sales & 2.14 & 0.98 & Low extent \\
\hline & Weighted average & 2.69 & 0.86 & High exten \\
\hline
\end{tabular}

Source: Field Survey, 2021.

\section{B. Test of Hypotheses}

The two null hypotheses of the study were tested using independent sample t-test and ANOVA. The null hypotheses were tested at 0.05 level of significance.

The summary of the test of hypotheses are presented in Tables III to IV as follows:

$\mathbf{H}_{01}$ : There is no significant difference in the mean ratings of entrepreneurs from Osun Central, Osun East and Osun West senatorial districts regarding the influence of internal business environment on the success of small and medium scale enterprises (SMEs).

TABLE III: ANALYSIS OF VARIANCE

\begin{tabular}{ccccccc}
\hline Sources & $\begin{array}{c}\text { Sum of } \\
\text { Squares }\end{array}$ & Df & $\begin{array}{c}\text { Mean } \\
\text { Square }\end{array}$ & F & Sig. & Decision \\
\hline $\begin{array}{c}\text { Between } \\
\text { Groups }\end{array}$ & 0.006 & 2 & 0.003 & & & \\
$\begin{array}{l}\text { Within } \\
\text { Groups }\end{array}$ & 50.937 & 203 & 0.251 & 0.012 & 0.988 & $\begin{array}{c}\text { Not } \\
\text { Rejected }\end{array}$ \\
Total & 50.944 & 205 & & & & \\
\hline \multicolumn{6}{l}{ Source: Field survey, 2021. }
\end{tabular}

The result of analysis of variance as presented in Table III reveals that the calculated value of $F$ was $0.012\left(F_{203}=0.012\right)$ and the observed probability value is 0.988 which is greater than the fixed probability value of $0.05(\mathrm{P}>0.05)$. This indicated that the null hypothesis which stated that, there is no significant difference in the mean ratings of entrepreneurs from Osun Central, Osun East and Osun West senatorial districts regarding the influence of internal business environment on the success of small and medium scale enterprises was not rejected.

Ho2: $_{\text {: }}$ There is no significant difference in the mean ratings of entrepreneurs from Osun Central, Osun East and Osun West senatorial districts regarding the influence of external business environment on the success of small and medium scale enterprises (SMEs).

\begin{tabular}{ccccccc}
\multicolumn{7}{c}{ TABLE IV: ANALYSIS OF VARIANCE } \\
\hline Sources & $\begin{array}{c}\text { Sum of } \\
\text { Squares }\end{array}$ & Df & $\begin{array}{c}\text { Mean } \\
\text { Square }\end{array}$ & F & Sig. & Decision \\
\hline $\begin{array}{c}\text { Between } \\
\text { Groups } \\
\text { Within }\end{array}$ & 0.787 & 2 & 0.393 & & & \\
$\begin{array}{c}\text { Groups } \\
\text { Total }\end{array}$ & 32.689 & 203 & 0.161 & 2.443 & 0.089 & $\begin{array}{c}\text { Not } \\
\text { Rejected }\end{array}$ \\
\hline Source: Field survey, 2021. & 205 & & & & \\
\hline
\end{tabular}

The result of analysis of variance as presented in Table IV reveals that the calculated value of $F$ was $2.443\left(F_{203}=2.443\right)$ and the observed probability value is 0.089 which is greater than the fixed probability value of $0.05(\mathrm{P}>0.05)$. This indicated that the null hypotheses which stated that, there is no significant difference in the mean ratings of entrepreneurs from Osun Central, Osun East and Osun West senatorial districts regarding the influence of external business environment on the success of small and medium scale enterprises was upheld.

\section{DISCUSSION OF FINDINGS}

The analysis of the first research question revealed that internal business environment influenced the success of small and medium scale enterprises (SMEs) to a high extent. The first null hypothesis was not rejected indicating that entrepreneurs did not differ significantly in their responses regarding the extent of influence of internal business environment on the success of small and medium scale enterprises based on senatorial districts. This is line with Rizal, Suhadak, and Kholid (2017) who indicated that internal environmental factors had a significant positive effect on business performance. The entrepreneur characteristics, management capacity, marketing skills and technological capacity are the factors of internal environment that have a significant effect on the business performance. The research question two which determined the extent to which external business environment influence the success of small and medium scale enterprises (SMEs) revealed that external business environment influenced the success of small and medium scale enterprises to high extent. This implied that a successful SMEs' venture depends largely on conducive and fascinating environment.

The second null hypothesis was accepted. This indicated that entrepreneurs did not differ significantly in their responses regarding the extent of influence of external business environment on the success of small and medium scale enterprises based on senatorial districts. These findings are supported by Ajayi (2016) who submitted that the external business environment (economic, political, legal, sociocultural environment, demographic, natural, technological, global, and financial environment) have influence on SMEs operations. 


\section{CONCLUSION}

The business environment is increasingly becoming complex, and businesses must become accustomed to the challenges posed by the complexity of the environment. It is obvious from the findings of this study that internal and external environment influenced the success of SMEs. Successful business operations require adequate knowledge of the environment in which the business is situated. Modern business environment demand proactive business strategies to combat emerging challenges. Therefore, SMEs operators must acquire necessary capacity to understand and mitigate the effects of external business to achieve their business visions and objectives.

\section{SUGGESTIONS}

The following suggestions were made based on the findings of the study:

1. SMEs business owners/managers must be abreast of the challenges posed by internal environment and put in place adequate internal control mechanism that will lead to optimal performance.

2. SMEs operators should be able to identify opportunities and threats in the external environment. This will enable them to mitigate threats and optimize opportunities for successful business operations.

3. Small and medium enterprise development agencies and government should collaborate in creating conducive environment for SMEs to survive.

\section{REFERENCES}

Adebisi, J. F., \& Gbegi, D. O. (2013). Effects of multiple taxations on the performance of small and medium scale business enterprises. (A study of West African Ceramics Ajaokuta, Kogi State). Mediterranean Journal of Social Sciences, 4, 324-334. doi:10.5901/mjss. 2013.v4n6p323.

Adeoye, A. O., \& Elegunde, A. F. (2012). Impacts of external business environment on organizational performance in the food and beverage industry in Nigeria, British Journal of Arts and Social Sciences 6(2), 213.

Aderibigbe, A. A. (2017). Appraisal of The Action of Osun State Government for The Development of Small and Medium-Sized Enterprises. Seinäjoki University of Applied Sciences, Faculty of Business and culture.

Agwu, M.O. \& Emeti, C.I. (2014) Issues, Challenges and Prospects of Small and Medium Scale Enterprises (SMEs) in Port-Harcourt City, Nigeria. European Journal of Sustainable Development, 3(1), pp. 101-114.

Ajayi, A (2016). Impact of External Business Environment on Organisational Performance of Small and Medium Scale Enterprises in Osun State, Nigeria. Scholedge International Journal of Business Policy \& Governance (ISSN 2394-3351), 3(10) 155-166.

Alaye-Ogan, E. (2012). A practical guide to running successful small businesses in Nigeria: challenges, peculiarities, and effective resolution support. Deutschland: Lambert Academic Publishing.

Alese, O.J. (2017). Strategic Management and The Development of Small and Medium Enterprises in South-West, Nigeria. An unpublished PhD Thesis of Olabisi Onabanjo University, Ogun state, Nigeria.

Alkali, M., \& Isa, A. H. (2012). Assessing the influence of external environmental factors on the performance of small business manufacturing enterprises in Bauchi State, Nigeria. Interdisciplinary Journal of Contemporary research in Business, 4(7), 621-628.

Blurtit. (2013). Definition of external and internal environment. Retrieved November 2016, from: http://businessfinance.blurtit.com/718404/what-is-the-external-andinternalenvironment-of-business.

Buowari, P.E. (2015). Factors Required for Small Business Sustainability in Nigeria (Doctoral thesis). Doctoral. Walden University.
Cherunilam, F. (2018). Business environment. Himalaya Publishing House Pvt. Ltd.

Chittithaworn, C., Islam, M. A., Keawchana, T., \& Yusuf, D. H. M. (2011). Factors affecting business success of small \& medium enterprises (SMEs) in Thailand. Asian Social Science, 7(5), 180-190.

Dugguh, S. I. (2013). Entrepreneurship and Small Business: Strategic Approach to Alleviating Poverty and Corruption. GSTF International Journal on Business Review, 3(1), 57-66. doi:10.5176/20104804 3.1.287.

Duncan, R. B. (1972). Characteristics of organizational environments and perceived environmental uncertainly. Administrative Science Quarterly Journal 29(1), 52-63.

Hans, V. B. (2018). Business Environment: conceptual framework and policies. International Educational Scientific Research Journal. 4(3), 67-74.

Kattookaran, T. P. (2016). Business Environment Study Material. University of Calicut School of Distance Education.

Kurtulus, Y. G. (2012). The response of the entrepreneurship to the changing business environment: strategic entrepreneurship. International Journal of Economic Administrative Studies, 5(9), 72-73.

Mazzarol, T., Clark, D. N., \& Reboud, S. (2014). Case Studies of Strategy, Planning, and Innovation in Australian Smes. Small Enterprise Research Journal, 21, 54-71. Retrieved from http:/www.seaanz.org/content/small-enterprise-researchjournalseaanz.

Ng, H. S., \& Kee, M. H. (2012). The issues and development of critical success factors for the SME success in a developing country. International Business Management, 6(6), 680-691.

Obiwuru, T. C., Oluwalaiye, O. B., \& Okwu, A. T. (2011). External and internal environment of businesses in Nigeria: An appraisal. International Bulletin of Business Administration Issue 12.

Okpara, J. O. (2011). Factors constraining the growth and survival of small and medium enterprises in Nigeria: implication for poverty alleviation. Management Research Review, 34(2), 156-171. DOI:10.1108/01409171111102786.

Onwukwe, V. C., \& Ifeanacho, M. I. (2011). Impact of government intervention on the growth of small and medium scale enterprises in Imo state. International journal of Research in Commerce, Economics and Management 1(7), 1-5

Rizal, O, Suhadak, M, \& Kholid, M (2017). Analysis of the influence of external and internal environmental Factors on business performance: a study on micro small and medium Enterprises (msmes) of food and beverage. RJOAS, 6(66), DOI https://doi.org/10.18551/rjoas.201706.05 .

Shehu, A. M., Aminu, I. M., NikMat, N. K., Nasiru, A., Johnson, P. O., Tsagem, M. M., \& Kura, K. M. (2013). The mediating effect between some determinants of SME performance in Nigeria. Management, 3 , 237-242. doi:105923/j.mm.20130304.07.

Small and Medium Development Agency of Nigeria (SMEDAN (2017). National survey of micro small and medium scale enterprises (MSMEs) 2017.Abuja: Small and Medium Development Agency of Nigeria (SMEDAN) and National Bureau of Statistics (NBS).

Walker, E., \& Brown, A. (2004). What success factors are important to small business owners? International Small Business Journal, 22 (6), $577-$ 593.

Watse, D. U. (2017). Sources of Financing for Small and Medium Enterprises in Nigeria (Walden Dissertations and Doctoral Studies Collection: Walden University). Retrieved from http://scholarworks.waldenu.edu/dissertations.

WebFinance http://www.businessdictionary.com/definition/success.html.

Yusuf, M. (2014). Hostile operating environment killing the manufacturing sector. Vanguard Newspaper. July 13, 2014. 